\title{
Overhoff, Jürgen
}

\section{"Geschichte ist etwas Fließendes." Lion Feuchtwanger's changing understanding of history and the role of the stage: from his earliest theatrical productions to his play Waffen für Amerika (1943/44)}

Zumhof, Tim [Hrsg.]; Johnson, Nicholas K. [Hrsg.]: Show, don't tell. Education and historical representations on stage and screen in Germany and the USA. Bad Heilbrunn : Verlag Julius Klinkhardt 2020, S. 31-48. - (Studien zur Deutsch-Amerikanischen Bildungsgeschichte / Studies in German-American Educational History)

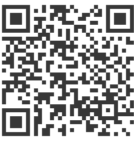

Quellenangabe/ Reference:

Overhoff, Jürgen: "Geschichte ist etwas Fließendes." Lion Feuchtwanger's changing understanding of history and the role of the stage: from his earliest theatrical productions to his play Waffen für Amerika (1943/44) - In: Zumhof, Tim [Hrsg.]; Johnson, Nicholas K. [Hrsg.]: Show, don't tell. Education and historical representations on stage and screen in Germany and the USA. Bad Heilbrunn : Verlag Julius Klinkhardt 2020, S. 31-48 - URN: urn:nbn:de:0111-pedocs-205091 - DOI: 10.25656/01:20509

https://nbn-resolving.org/urn:nbn:de:0111-pedocs-205091

https://doi.org/10.25656/01:20509

in Kooperation mit / in cooperation with:

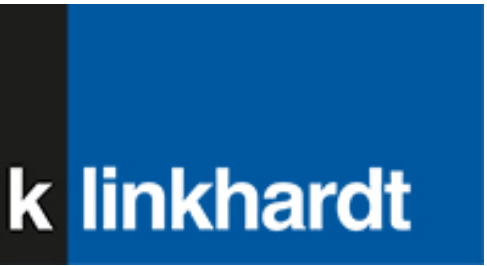

http://www.klinkhardt.de

\section{Nutzungsbedingungen}

Dieses Dokument steht unter folgender Creative Commons-Lizenz: http://creativecommons.org/licenses/by-nc-sa/4.0/deed.de - Sie dürfen das Werk bzw. den Inhalt unter folgenden Bedingungen vervielfältigen, verbreiten und öffentlich zugänglich machen sowie Abwandlungen und Bearbeitungen des Werkes bzw. Inhaltes anfertigen: Sie müssen den Namen des Autors/Rechteinhabers in der von ihm festgelegten Weise nennen. Dieses Werk bzw. der Inhalt darf nicht für kommerzielle Zwecke verwendet werden. Die neu entstandenen Werke bzw. Inhalte dürfen nur unter Verwendung von Lizenzbedingungen weitergegeben werden, die mit denen dieses Lizenzbedingungen weitergegeben werden,

Mit der Verwendung dieses Dokuments erkennen Sie die Nutzungsbedingungen an.

\section{Terms of use}

This document is published under following Creative Commons-License: http://creativecommons.org/licenses/by-nc-sa/4.0/deed.en - You may copy, distribute and transmit, adapt or exhibit the work in the public and alter, transform or change this work as long as you attribute the work in the manner specified by the author or licensor. You are not allowed to make commercial use of the work. If you alter, transform, or change this work in any way, you may distribute the resulting work only under this or a comparable license.

By using this particular document, you accept the above-stated conditions of

\section{Kontakt / Contact:}

\section{DeDOCS}

DIPF | Leibniz-Institut für Bildungsforschung und Bildungsinformation Informationszentrum (IZ) Bildung

E-Mail: pedocs@dipf.de

Internet: www.pedocs.de

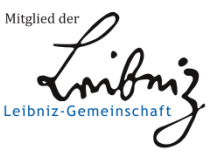




\section{Studien zur Deutsch-Amerikanischen}

Bildungsgeschichte / Studies in German-American Educational History

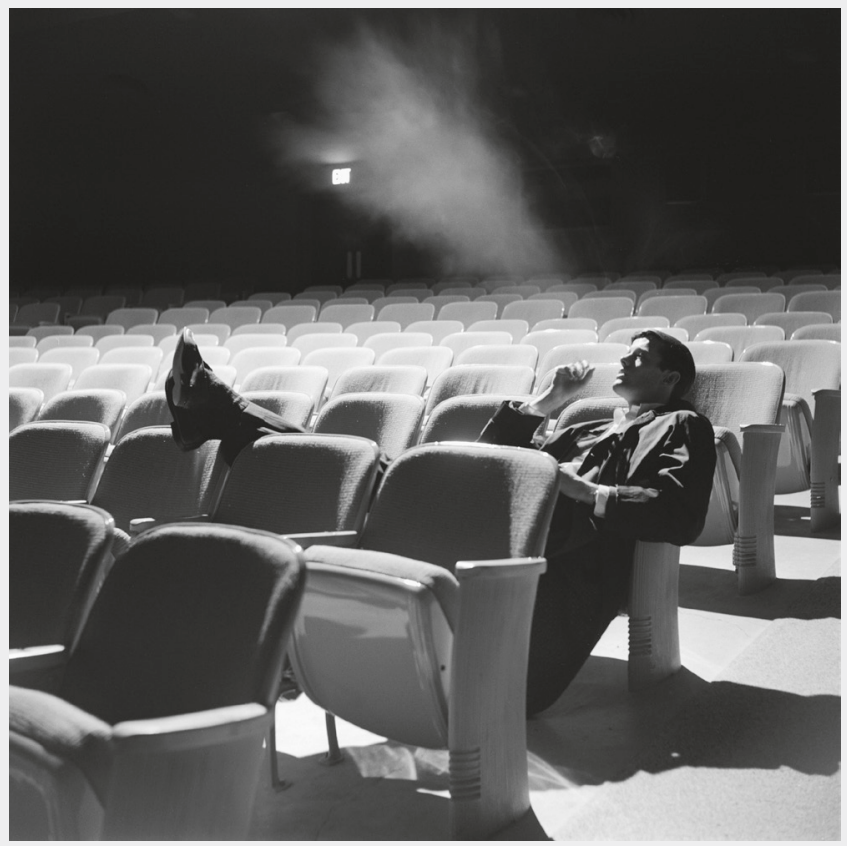

Tim Zumhof

Nicholas K. Johnson (eds.)

Show, Don't Tell

Education and Historical Representations on Stage and Screen in Germany and the USA 


\section{Zumhof / Johnson Show, Don't Tell}


Studien zur Deutsch-Amerikanischen Bildungsgeschichte Studies in German-American Educational History

General Editor Jürgen Overhoff 


\section{Tim Zumhof \\ Nicholas K. Johnson (eds.)}

\section{Show, Don't Tell}

Education and Historical Representations on Stage and Screen in Germany and the USA 
This volume was published in cooperation with the Center for German-American Educational History at the University of Münster.

Titel entstand in Kooperation mit der „Arbeitsstelle für Deutsch-Amerikanische Bildungsgeschichte".

\section{Arbeitsstelle für Deutsch-Amerikanische Bildungsgeschichte}

Dieser Titel wurde in das Programm des Verlages mittels eines Peer-Review-Verfahrens aufgenommen. Für weitere Informationen siehe www.klinkhardt.de.

Bibliografische Information der Deutschen Nationalbibliothek

Die Deutsche Nationalbibliothek verzeichnet diese Publikation in der Deutschen Nationalbibliografie; detaillierte bibliografische Daten sind im Internet abrufbar über http://dnb.d-nb.de.

2020.lg. (C) by Julius Klinkhardt.

Bildnachweis Umschlagseite 1: (C) Francis Miller (1961). Peter Fonda in theater audience seats at Omaha Nebraska Community Playhouse. The LIFE Picture Collection via Getty Images. - The cover photo is used for illustrative purposes only and does not represent an endorsement by the Peter Fonda estate.

Druck und Bindung: AZ Druck und Datentechnik, Kempten.

Printed in Germany 2020.

Gedruckt auf chlorfrei gebleichtem alterungsbeständigem Papier.

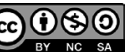

Die Publikation (mit Ausnahme aller Fotos, Grafiken und Abbildungen) ist veröffent-

licht unter der Creative Commons-Lizenz: CC BY-NC-SA 4.0 International

https://creativecommons.org/licenses/by-nc-sa/4.0/

ISBN 978-3-7815-5828-1 Digital

doi.org/10.35468/5828

ISBN 978-3-7815-2397-5 Print 


\section{Table of Contents}

Nicholas K. Johnson and Tim Zumhof

"Are you not entertained?" -

Education, Entertainment, and Historical Representations

on Stage and Screen in Germany and the USA, an Introduction .7

Tim Zumbof

Historical Culture, Public History, and Education

in Germany and the United States of America.

A Comparative Introduction to Basic Concepts and Fields of Research.

Jürgen Overhoff

"Geschichte ist etwas Fließendes."

Lion Feuchtwanger's Changing Understanding of History

and the Role of the Stage: From his Earliest Theatrical Productions

to his Play Waffen für Amerika (1943/44)

Simon Richter

Duell an der Havel:

Fritz von Unruh's Depiction of Eighteenth-Century

Prussian-American Relations

Alissa Rubinstein

The 614th Commandment:

A Documentary Play about how American Jews Feel

about Germany Today

Wolfgang Hochbruck

Living History as an Educational Tool and Method

in North America and Germany

Stephanie Johns

Theatre, Education, and Public History:

Teaching History at the Stratford Festival 
6 Table of Contents

Felix Apel

Hollywood's Influence on the Transmission of Historical Images:

Lars Kraumes' Der Staat gegen Fritz Bauer

Thorsten Carstensen

Learning from John Ford:

History, Geography, and Epic Storytelling in the Works of Peter Handke

Raymond Haberski, Jr.

The Passion of Richard Schickel: What We Expect from War Films

160

Nicholas K. Johnson

"A classroom history lesson is not going to work":

HBO's Conspiracy and Depicting Holocaust Perpetrators on Film

Table of Figures

List of Contributors

Index

Acknowledgements 
Jürgen Overhoff

\section{"Geschichte ist etwas Fließendes." Lion Feuchtwanger's Changing Understanding of History and the Role of the Stage: From his Earliest Theatrical Productions to his Play Waffen für Amerika $(1943 / 44)$}

\section{Biographical Background - A Predilection for History}

Lion Feuchtwanger ${ }^{1}$ was one of the best known and the most successful German-speaking writers of the twentieth century. English translations of his novels reached millions of readers, especially in the United States of America, the land of his exile, where Feuchtwanger died in 1958 near Los Angeles in his marvelous and more than stately home, the Villa Aurora in Pacific Palisades, a house designed in the grand Spanish style. The sheer sight of the Villa Aurora - bought by Feuchtwanger in 1943 and now funded and maintained as an historic landmark by the Berlin-based Villa Aurora \& Thomas Mann House e.V., and the Friends of Villa Aurora Inc., Los Angeles ${ }^{2}$ - still indicates to the mindful observer how immensely rich the author had become by selling his myriad of books. If the term "best-selling author" means something, then it certainly does with regard to Feuchtwanger, a tremendously talented writer whose books turned to gold almost instantly after their release.

Despite his stunning outward success, Feuchtwanger's private life was not free from tragedy; his only daughter died as a baby, a most painful loss he never fully came to terms with. As a Jew, he was persecuted and driven out of Germany by the National Socialists after they seized power in 1933. He had anticipated this catastrophic triumph of fascism three years earlier in his novel Erfolg (Success), published in $1930 .^{3}$ Towards the end of his life, during the inglorious years of the

1 On Feuchtwanger's biography see Reinhold Jaretzky. Lion Feuchtwanger (Reinbek bei Hamburg Rowohlt, 1984); Andreas Heusler. Lion Feuchtwanger. Münchner - Emigrant - Weltbürger (Salzburg: Residenz, 2014); Wilhelm von Sternburg. Lion Feuchtwanger. Die Biografie (Berlin: Aufbau, 2014).

2 See Villa Aurora, URL: https://www.vatmh.org/en/artists-residence.html (accessed September 6, 2019).

3 Lion Feuchtwanger. Erfolg. Drei Jahre Geschichte einer Provinz (Berlin: Gustav Kiepenheuer, 1930). 
McCarthy era, long after he had moved to California, the aged author became the target of permanent suspicion as a left-wing intellectual with sympathies for democratic socialism or even Soviet Communism. In 1957, the much-troubled Feuchtwanger became ill with stomach cancer, a lethal and cruel disease. After several operations, he died from internal bleeding in late December 1958, three days before Christmas, aged 73 .

Feuchtwanger's life had begun in the Kingdom of Bavaria, a proud and traditional southern state of the German Empire. He was born on 7 July 1884 in the Bavarian capital Munich, firstborn son to Orthodox Jews Johanna and Sigmund (Aaron Meir) Feuchtwanger. Sigmund Feuchtwanger's ancestors originated from the imperial free city of Feuchtwangen in Franconia, and they had experienced anti-Judaism long before the Nazis rose to power. Following a 1555 pogrom, the city of Feuchtwangen had expelled all of its resident Jews ${ }^{4}$, some of whom found a new home in Fürth, where they were simply called "the Feuchtwangers," meaning those Jews from Feuchtwangen. ${ }^{5}$ In the middle of the nineteenth century, it was Sigmund Feuchtwanger's father Elkan who then moved with his family from Franconia to Munich. There, in the times of the new Kaiserreich of 1871, when Jews enjoyed full civil rights for the first time in German history, Lion's father became a wealthy entrepreneur and owner of the well-known margarine and butter factory "Saphir-Werke."

Sigmund could now afford a comfortable lifestyle and a very decent education for all of his nine children. While Lion, the firstborn, certainly became the most prominent member of the large Feuchtwanger family, it is worth noting that his brothers Martin and Ludwig became authors, too; Ludwig's son is the British historian Edgar Feuchtwanger. ${ }^{6}$ Two of Lion's sisters moved to Palestine following the rise of the Nazi Party. One sister, Bella, stayed in Germany; in 1943, she died in the concentration camp Theresienstadt. Another sister left Germany - like Lion, for America; she settled in New York.

Lion grew up in the Bavarian Capital; Munich was a place he liked and fondly considered his home. He identified, sometimes ironically, with the Bavarian way of life, and throughout his life, he spoke with a heavy Bavarian accent, even in

4 See Dietrich Weiß. Aus der Geschichte der jüdischen Gemeinde von Feuchtwangen 1274-1938 (Feuchtwangen, 1991). 19.

5 Sternburg, Feuchtwanger, 16-17. More generally on Feuchtwanger's family: Heike Specht. Die Feuchtwangers. Familie, Tradition und jüdisches Selbstverständnis im deutsch-jüdischen Bürgertum des 19. und 20. Jahrhunderts (Göttingen: Wallstein, 2006).

6 Edgar Feuchtwanger's memoirs of his childhood as a Jewish boy in the Weimar Republic appeared in 2017: Edgar Feuchtwanger and Bertil Scali. Hitler, My Neighbor. Memories of a Jewish Childhood, 1929-1939 (New York: Other Press, 2017).

7 Rolf Selbmann describes Lion Feuchtwanger and his parents as "kulturell nicht nur Deutsche, sondern ausgesprochene Bajuwaren," see: Rolf Selbmann. "'Hat in der Geschichte nicht immer entsprochen'. Lion Feuchtwanger als Schüler des Wilhelmsgymnasiums. Zu seinem 100. Geburtstag," in 
English - but he also identified with his Jewish ancestry. In his hometown, he went to the prestigious Wilhelmsgymnasium, an elite school for boys, where he passed his final exam, the Abitur, with distinction in 1903. In addition, his father paid for a part-time home education: At least one hour per day, Lion had to study the Aramaic Talmud and the Hebrew Bible. ${ }^{8}$ He then took up his university studies, first in Munich, and then in Berlin after 1904. As a student with a wide range of interests, he read history, philosophy, anthropology, Sanskrit, and, above all, German language and literature. He received his doctorate in 1907.

Like many German Jews with literary talents, Feuchtwanger was inspired and heavily influenced by the writings of the greatest German-Jewish author of the nineteenth century, Heinrich Heine. He was attracted by the many visible parallels ${ }^{9}$ between Heine's Jewish existence and his own life. It therefore does not come as a surprise that Feuchtwanger wrote a careful analysis of the motives and literary strategies of Heine's 1840 fragment of a novel Der Rabbi von Bacharach (The Rabbi of Bacharach) as the subject of his $\mathrm{PhD}$ dissertation. ${ }^{10}$ Der Rabbi von Bacharach was Heine's attempt to reflect upon his Jewish identity as a German writer by describing an episode of German-Jewish history dating back to the Middle Ages. Clearly, Heine became a role model for Feuchtwanger. Throughout his life, especially when he had successfully set himself up as an immensely popular writer, Feuchtwanger preferred to depict episodes from history - and from Jewish history in particular ${ }^{11}$ - in order to teach his readers valuable and important lessons about the human condition.

\section{Feuchtwanger as a Theater Critic and Playwright}

Today, Feuchtwanger is best remembered as an accomplished author of historical novels - but when he started to write, he was first known as a playwright. During his years as a student, he had already become deeply interested in all sorts of theatrical

Wilhelmsgymnasium in München. Jahresbericht 1983/84, ed. by Wilhelmsgymnasium (München, 1984), 94-106. 97.

8 See Lion Freuchtwanger. "Meine Schulzeit," in Federleichte Mädchen. Das nymphenburger Lesebuch, ed. by Dietz-Rüdiger Moser (München: Nymphenburger, 1991), 200-202. 201.

9 Sternburg, Feuchtwanger, 47: "Manches, was Lion Feuchtwanger über Heines Werdegang schreibt, weist Parallelen zur eigenen Glaubens- und Lebenskrise auf."

10 Feuchtwanger's PhD-thesis was published posthumously: Lion Feuchtwanger. Heinrich Heines "Der Rabbi von Bacherach". Eine kritische Studie (Frankfurt am Main: Fischer, 1985).

11 Feuchtwanger wrote about very different episodes of 3000 years of Jewish history. His novels focus on episodes from the Old Testament, "Jefta und seine Tochter [Jefta and his Daughter]" (Hamburg 1957); Antiquity: "Der Jüdische Krieg [The Judean War]," (Berlin 1932); the Middle Ages, "Die Jüdin von Toledo [Raquel, the Jewess of Toledo]," (Berlin 1955); The Age of Enlightenment: "Jud Süß [Jew Süss]," (München 1925). 
productions. He composed a historical one-act play about King Saul, the legendary Old Testament ruler of Israel, reflecting on Saul's conflicts and his complicated attitude towards young David. On 21 September 1905, this play, in the Romantic style of the Irish poet Oscar Wilde, was put on stage at the Munich Volkstheater, but failed to convince the audience. All further performances were canceled. ${ }^{12}$ This was a humbling experience, and Feuchtwanger was deeply embarrassed. He felt the need to learn more about other authors' successful productions before starting out anew. In the meantime, he tried to pursue a career as a professional theater critic, writing lengthy and insightful reviews of numerous plays.

Feuchtwanger soon managed to earn his living as a journalist. In 1908, he founded the culture magazine Der Spiegel. Münchener Halbmonatsschrift für Literatur, Musik und Bühne. The first issue appeared on 30 April. Prominent authors such as Thomas Mann, Waldemar Bonsels, or Arthur Kutscher contributed articles, reviews, and essays of the highest literary quality. Feuchtwanger himself wrote almost exclusively theater reviews, but also wrote lengthy theoretical reflections on the work of his heroes Heine and Wilde. ${ }^{13}$ After 15 issues and six months, Der Spiegel merged with Siegfried Jacobsohn's famous journal Die Schaubühne (The Stage) and was later renamed Die Weltbühne (The World Stage), for which Feuchtwanger continued to write many witty and insightful feuilleton articles - around 200 pieces - on first night performances and theater premieres, mostly in Germany and Austria. The scope of his interest ranged from the productions of Max Reinhardt, the great innovator of staging techniques, design and choreography, to the much more rustic and folkloristic Oberammergau Passion Plays. ${ }^{14}$

In 1912, he married Marta Löffler, the daughter of a Jewish merchant. During the first year of their marriage, Marta gave birth to a daughter, Marianne, but the child tragically died only a few weeks after birth. The devastated couple tried to console themselves by traveling throughout Southern Europe. Their vagabondage lasted for two years. Sometimes they just resided somewhere on the Mediterranean coast, simply staring at the foaming waves, in order to forget. But, from time to time, Feuchtwanger also watched theater performances, wrote trenchant reviews, and sent them to Germany, to be published in the Schaubühne. One of these articles was dedicated to the festival of Syracuse in Sicily, praising its spectacular ancient theater, a magnificent structure preserved since the age of the Greek colonists. Feuchtwanger called this unique theater - marvelously set against

12 Hans Dahlke. "Nachwort. Lion Feuchtwanger als Dramatiker," in Lion Feuchtwanger: Dramen II, ed. by Hans Dahlke (Berlin: Aufbau, 1984), 685-718. 691.

13 See Lion Feuchtwanger. "Heinrich Heine und Oscar Wilde. Eine psychologische Studie," in Lion Feuchtwanger Ein Buch nur für meine Freunde (Frankfurt am Main: Fischer, 1984), 17-30. This article was first published in: Der Spiegel, Nr. 12, September 30, 1908.

14 See Sternburg, Feuchtwanger, 77-78. 
the horizon of the blue sea - the "most powerful theater my poor eyes have ever seen." 15

Immediately after the outbreak of the Great War in the summer of 1914, the 28-year old Feuchtwanger moved back to Germany, where he served in the Royal Bavarian Army. He was soon released from his duties for health reasons. Still, his brief but shocking experience as a soldier decisively contributed to the development of his political stance. He became a fierce critic of the authoritarian, militaristic, belligerent, and outdated Wilhelmine Empire - and he became a wholehearted Republican. In November 1918, when Germany was defeated and the Kaiser fled to the Netherlands during the early days of the German Revolution, Feuchtwanger welcomed the establishment of the new German republic, the new German democracy - the so-called Weimar Republic.

The renowned and ambitious journalist sought to find his way in the challenging political realities of the new German republic by trying to redefine himself as a professional playwright. This time, he had more success than in the pre-war era. According to a careful count by Eckhard Schulz, Feuchtwanger's plays were performed in the "roaring" 1920s around 5,000 times on the most important stages in Germany. ${ }^{16}$ Already during the war years, he had written three new pieces on historical episodes dating from the Renaissance to the Age of Enlightenment. Now, after the Revolution, he focused on the most recent part of history, the rapid transition from monarchy to democracy in Bavaria, Austria, and Germany as a whole.

In his play Thomas Wendt - finished in 1919 and renamed Neunzehnhundertachtzehn (1918) in 1934 - he tried to reflect upon the Revolution's decisive months. The play's protagonist, Thomas Wendt, stumbles between hope and despair. On the one hand, he rejoices: "Benevolence disseminated among humans, happiness for all men - that is the true sense of our revolution." ${ }^{17}$ On the other hand, he begins to realize that the heroic goals of the Revolution are threatened by politicians who seek power for the sake of power. Disillusioned and embittered, he cries out: "Leave me alone. I am done with it. I do not want politics any longer." 18

15 "[das] mächtigste Theater, das meine armen Augen je gesehen, Lion Feuchtwanger," "Aischylos, Syrakus und Reinhardt," in Lion Feuchtwanger, Ein Buch nur für meine Freunde (Frankfurt am Main: Fischer, 1984), 173. - This article was first published in: Die Schaubühne, Nr. 20, May 14, 1914.

16 Eckhard Schulz. "Lion Feuchtwanger als Dramatiker.” Volksbühnen-Spiegel 18.7/8 (1972): 30.

17 "Güte von Mensch zu Mensch, Glück für alle, das ist der Sinn unserer Revolution," "Neunzehnhundertachtzehn. Ein dramatischer Roman," in Lion Feuchtwanger: Dramen I, ed. by Hans Dahlke (Berlin: Aufbau, 1984), 580.

18 "Laßt mich. Ich will nicht mehr. Ich will keine Politik mehr," "Neunzehnhundertachtzehn. Ein dramatischer Roman," in Lion Feuchtwanger: Dramen I, ed. by Hans Dahlke (Berlin: Aufbau, 1984), 589. 
The audience is left to decide for themselves what to think of the new political order.

While Feuchtwanger reinvented himself as an avant-garde intellectual of the new Republic, he discovered another promising young playwright, a similarly and extremely self-conscious Bavarian from the city of Augsburg. This fellow-countryman, a rising star of the literary scene in Germany, was Bertolt Brecht. ${ }^{19}$ Feuchtwanger and Brecht became colleagues and close friends. Their friendship became lasting and permanent. For Brecht had to leave Germany after the rise of the Nazis, too, and, like Feuchtwanger, he would stay in Californian exile for many years. In the 1920s, both men started to collaborate and Feuchtwanger took a genuine interest in the drafts of Brecht's early work.

In 1924, they even wrote a play together, a history drama set in England between 1307 and 1326, Leben Eduards des Zweiten von England (The Life of Edward II of England). According to Feuchtwanger's wife Marta, her husband also suggested the titles of a number of Brecht's other works, including Trommeln in der Nacht (Drums in the Night) (originally titled Spartakus). ${ }^{20}$ Feuchtwanger, a bourgeois in manner and demeanor, was often annoyed by Brecht's arrogant and somewhat undisciplined air of a laidback bohemian - but he always respected and recognized him as a true genius. ${ }^{21} \mathrm{He}$ also witnessed the development of Brecht's theory of the Epic Theater (Episches Theater) with its political and educational mission, which came to full fruition in 1926.

\section{Feuchtwanger's Critique of Epic Theater's Educational Mission}

The theory of Epic Theater was not Brecht's own original invention. He did not claim, as it were, a copyright. It was a theatrical ideal that arose around the beginning of the twentieth century from the theories and experiments of a number of avant-garde theater practitioners who responded to the political challenges of the time through the creation of a genuinely political and educational theater. Epic Theater seeks to provoke the audience's immediate reaction, forcing all those traditionally passive viewers of colorful spectacles to finally get engaged and involved in the politics of their day and age. Epic Theater is a mixture of political activism and political education.

19 Feuchtwanger writes about his first meeting with Brecht in his diary: "1919, 2. April: Ein junger Mensch bringt ein ausgezeichnetes Stück. Bert Brecht," Feuchtwanger, Lion. Ein möglichst intensives Leben. Die Tagebücher, ed. by Nele Holdack, Marje Schuetze-Coburn, and Michaela Ullmann (Berlin: Aufbau, 2018), 215.

20 See Sternburg, Feuchtwanger, 210.

21 See Sternburg, Feuchtwanger, 210. 
It was the German theater producer Erwin Piscator who first introduced the term "Epic Theater." 22 Piscator coined it when he became director of Berlin's Volksbühne in 1924 - exactly the same year when Brecht and Feuchtwanger began their collaboration. Piscator aimed to interest young playwrights in issues related to contemporary political life. He also asked them to stage their theatrical productions by using documentary effects, coming up with strategies to cultivate a direct response, and aiming for audience interaction. Brecht discussed the priorities and approach of Piscator's Epic Theater with Feuchtwanger. Then Brecht unified them, developed the approach, and popularized it.

Brecht's theater performances and stage plays would always include a subsequent moment of understanding and comprehension - a pedagogical moment - where he wanted to make sure that the audience got the message, sometimes by having actors speaking directly to the audience. The use of a narrator in his 1944 play Der Kaukasische Kreidekreis (The Caucasian Chalk Circle) is a prominent example of this technique. The narrator accompanies and explains the dynamics of the performance continuously. Brecht's epic approach also utilized montage techniques of interruptions, fragmentation, and contradiction.

In his best summary of the pedagogical principles of the Epic Theater, a short essay titled "Vergnügungstheater oder Lehrtheater" (Theater for Pleasure or Theater for Instruction), unpublished in Brechts's lifetime and probably written around 1936, the playwright counters all sorts of objections put forward by his critics. Contrary to their assertions, Brecht contends, an educational theater is not necessarily a boring affair. Brecht admits that "there is much that is tedious about the kind of learning familiar to us from school," ${ }^{23}$ but he does not find theatrical instructions similar to forms of classical schooling. "Theater remains theater even when it is instructive theater," he emphasizes, "and in so far it is good theater it will amuse."24

To make his point in the most persuasive manner, Brecht even refers to Friedrich Schiller, whom he considered to be one the greatest playwrights of all time. Schiller also considered the theater to be an educational and a moral institution, but in making this demand, as Brecht argues, "it hardly occurred to Schiller that

22 See Christopher Innes. Erwin Piscator's Political Theater: The Development of Modern German Drama (Cambridge: Cambridge University Press, 1977).

23 "Unzweifelhaft ist das Lernen, das wir aus der Schule, aus den Vorbereitungen zum Beruf und so weiter kennen, eine mühselige Sache," Bertolt Brecht. "Vergnügungstheater oder Lehrtheater," in Werke. Große kommentierte Berliner und Frankfurter Ausgabe, ed. by Werner Hecht, Jan Knopf, Werner Mittenzwei, and Klaus-Detlef Müller, Vol. 22: Schriften 2, Teil 1 (Berlin, Weimar, Frankfurt: Aufbau, Suhrkamp, 1992), 106-116. 111.

24 "Das Theater bleibt Theater, auch wenn es Lehrtheater ist, und soweit es gutes Theater ist, ist es amüsant," Brecht, Werke, 22. 112. 
by moralizing from the stage he might drive the audience out of the theater." ${ }^{25} \mathrm{In}$ fact, Schiller knew of "nothing that could give greater amusement and satisfaction than the propagation of ideas." ${ }^{26}$ Since in Brecht's eyes, Epic Theater propagated important ideas, therefore it was both an educational and a highly amusing kind of theatrical production.

As far as the contents of his play were concerned, Brecht preferred to put episodes from history on stage. Again, he resembled Schiller, who in his "Die Schaubühne als Moralische Anstalt" had advocated the use of episodes from history in theatrical productions. If the theater shall effect, bring about, and entertain a deeply moving kind of education, then the playwright, the intendant of the theater, and the actors must be interested in presenting to the audience important episodes from the history of mankind. Then, looking back at history, we can see our own limits, our potentials, and we can draw lessons from what we have seen and experienced in the theater. ${ }^{27}$

In making use of history as Schiller did, Brecht liked to draw connections from a historical incident to very similar current events. This had already been the case in Leben Eduards des Zweiten von England, a play set in late-medieval England, and it was later masterly repeated in his famous plays Mutter Courage und ihre Kinder (Mother Courage and Her Children) and "Leben des Galilei" (Life of Galileo). The first play sought to reconstruct social and political affairs during the Thirty Years War in Germany, alluding to the historical context of the years 1626 to 1636; the second play was set in the first half of the seventeenth century in the Republic of Venice.

Despite their close friendship, Feuchtwanger's approach to theater differed from Brecht's style in a variety of aspects. While episodes from history played a prominent role in Feuchtwanger's plays, too - for example, Kalkutta, 4. Mai (Calcutta, $4^{\text {th }}$ May) of $1925^{28}$ - In the 1920 s, Feuchtwanger did not want to teach a pedagogical lesson from history in his plays. He wanted to portray the psychological preconditions of human behavior in general; he was interested in "general psychological facts." ${ }^{29}$ Thus, he explicitly stated that in his play Kalkutta, 4. Mai, he did "not want do give a straightforward representation of $18^{\text {th }}$ century Anglo-Indian

25 "[Es] kam [Schiller] kaum in den Sinn, daß er dadurch, daß er von der Bühne herab moralisierte, das Publikum aus dem Theater treiben könnte," Brecht, Werke, 22. 114.

26 "nichts, was amüsanter und befriedigender sein konnte, als Ideale zu propagieren," Brecht, Werke, 22. 115 .

27 Schiller's constant use and adaptation of history in his plays and writings is excellently discussed in Peter-André Alt. Schiller. Eine Biographie, vol. 1 (1759-1791) (München: C. H. Beck, 2000), 587-675.

28 This play is about Warren Hastings (6 December 1732 - 22 August 1818), an English statesman, who was the first Governor-General of India from 1773 to 1785.

29 "psychologische Grundtatsachen," Lion Feuchtwanger. "Vorwort zu den 'Drei Stücken'," in Lion Feuchtwanger: Dramen II, ed. by Hans Dahlke (Berlin: Aufbau, 1984), 666. 
politics." ${ }^{30}$ In 1929, looking back on his theatrical productions, he stated: "Please, do not expect from my plays some sort of historical lesson." ${ }^{11}$ Only a few years later, however, during the years of the Nazi regime, Feuchtwanger's attitude changed. His biographical experiences mattered.

\section{Asylum - France, the Soviet Union, and the United States of America}

In 1933, when Adolf Hitler became Chancellor of Germany and when the National Socialist Party ruthlessly and mercilessly persecuted the entire political opposition and, above all, the Jews, Feuchtwanger's plays were banned from the German stage - everywhere, overnight and at once. In the early 1920s, Feuchtwanger had been one of the very first to produce propaganda against Hitler and the Nazi Party in the form of satirical texts. Both Feuchtwanger's Judaism and his early, fierce criticism of the Nazi Party ensured that he would be a target of systematic state-sponsored persecution immediately after Hitler's appointment as chancellor in January 1933. On the same day that Hitler was appointed leader of the German government by President Paul von Hindenburg, Feuchtwanger was on a speaking tour in the United States: On 30 January 1933 he was invited to a festive dinner in Washington D.C., hosted by the then German ambassador to the US, Friedrich Wilhelm von Prittwitz und Gaffron. The next day, Prittwitz resigned from his duties as German diplomat - and he recommended that Feuchtwanger stay away from Germany for good. This is what Feuchtwanger did; he did not return to Berlin.

At home, in Germany, his works and published plays were included among those books thrown into the flames of the Nazi book burning held across Germany on 10 May 1933. Feuchtwanger could have stayed in Washington, but in 1933, he was not yet willing to settle in America - he was not prepared to leave Europe behind. He did not return to Germany, of course, but moved to Southern France, settling in Sanary-sur-Mer. There, he continued to fight the fascist and racist ideology of the Third Reich. In 1936, still in Sanary-sur-Mer, he wrote the historic novel Der falsche Nero (The Pretender), in which he compared the Roman Terentius Maximus, who had pretended to be Nero, with the Austrian upstart Hitler. Deeply concerned about the lack of any forthright anti-Nazi attitude among the Western powers Britain and the USA, he became curious about Soviet commu-

30 "keine eindeutige Darstellung der anglo-indischen Politik im 18. Jahrhundert," Feuchtwanger, Vorwort zu den "Drei Stücken", 664.

31 "Erwarten Sie, bitte, von diesen Stücken keine historische [...] Belehrung," Feuchtwanger, Vorwort zu den "Drei Stücken," 664. 
nism. From November 1936 to February 1937, he traveled the Soviet Union. In his travel impressions of Moscow in 1937, he had many good things to say about life under Stalin. Later, these notes from Russia were severely criticized by his friends as incredibly naïve, but Feuchtwanger was certainly right in assuming that Hitler could only be defeated if the United States, Britain, and the Soviet Union would become allies and join forces against Nazi Germany. This is what happened only a few years later, when the American president Franklin D. Roosevelt, the British prime minister Winston Churchill, and the Soviet leader Joseph Stalin formed an alliance against Hitler.

When France declared war on Germany in 1939, Feuchtwanger moved to Nîmes because of the surprisingly fast advance of German troops. From there, he escaped to Marseille in a most fanciful disguise: The playwright Feuchtwanger, in a life-threatening, crucial moment of his existence - played the role of a woman. He acted on a stage called real life; and he succeeded as an actor when playing the role of his life. From Marseille, he was able to flee with his wife Marta to the United States via Spain and Portugal. He escaped with the help of Varian Fry, a journalist and member of the American Emergency Rescue Committee. ${ }^{32}$ The Feuchtwangers decided to finally leave the Old World behind - and they sailed from Lisbon on board the ship "Excalibur" without further delay to New York City, where they were greeted, on 5 October 1940, by the Statue of Liberty. The time of Feuchtwanger's asylum in the United States of America had begun. ${ }^{33}$

As soon as Feuchtwanger had been officially granted political asylum in the United States, he left New York for California and settled in the vicinity of Los Angeles in 1941, when he published a memoir of his internment, Der Teufel in Frankreich (The Devil in France). In 1943, Feuchtwanger bought the Villa Aurora in Pacific Palisades, California. Here one might ask how it came to be that the refugee Feuchtwanger was in a position to buy and finance a wonderful and expensive Spanish-style house? The simple and straightforward answer is that by then, Feuchtwanger was very well-known throughout the United States. Many of his writings had been translated and become bestsellers in the New World.

In the mid-1940s, his most popular novel in the United States was Jud Süß (Jew Suss), originally published in Germany in 1925. It was based on a play he had written as early as 1916 . The novel is set in the eighteenth century and tells the story of the Jewish businessman Joseph Süß Oppenheimer, who is accused of lecherous relations with the ladies of the court of Duke Karl Alexander of Württemberg. Yet, not only is he found innocent, but he also discovers that he is the illegitimate son of a Christian nobleman. When sentenced to death, he does not

32 See Sternburg, Feuchtwanger, 416.

33 See Sternburg, Feuchtwanger, 423. 
reveal his Christian origins. Instead, he decides to hold fast to Judaism. When dying, he recites the Shma Yisrael, the most important prayer in Judaism.

Feuchtwanger's moving novel was extremely well-received by readers in Europe and America. Within the first year of its appearance, it went through five printings. By 1931, it had been translated into 17 languages. This tremendous success established Feuchtwanger as a major international author and it allowed him to live a life of financial independence. In Germany, the NSDAP filmed their own anti-Semitic version of the story with the very same title of Feuchtwanger's novel. The Nazi film industry's version of Jud Süß, directed by Veit Harlan, was released in 1940. The anti-Semitic film portrays Oppenheimer in an entirely different light than the original. The Nazis perverted the intention of Feuchtwanger's book.

In his American exile, Feuchtwanger made Pacific Palisades, California, his new home because this was the place where many of the famous exiled German writers and artists had already settled. Thomas Mann, Heinrich Mann, Theodor W. Adorno, Alfred Döblin, Franz Werfel, Arnold Schönberg, and Fritz Lang, to name just a few, and, of course, Feuchtwanger's old and close friend Bertolt Brecht all lived in or around Los Angeles. The intellectual elite of the Weimar Republic now lived together as if they were in a small village. Pacific Palisades in particular became a unique place in the history of German-American relations, an almost mythical place. It became what has been aptly called a "New Weimar," or, a true "Weimar on the Pacific." 34

\section{Writing Against the Nazis and their Ideology - Feuchtwanger's Play "Waffen für Amerika" (1943/1944)}

Immediately after he had bought the Villa Aurora, Feuchtwanger wanted to express his gratitude to America as a safe haven, a sanctuary where he had eventually found rest and political asylum. In December 1943, ${ }^{35}$ the grateful Feuchtwanger began to write a play about one of the greatest characters of American history, Benjamin Franklin ${ }^{36}$, founding father of the American republic and architect of

34 See Erhard Bahr. Weimar on the Pacific. German Exile Culture in Los Angeles and The Crisis of Modernism (Berkeley and Los Angeles: University of California Press, 2007). For more on the German exiles in California, see Anthony Heilbut. Exiled in Paradise. German Refugee Artists and Intellectuals in America from the 1930s to the Present (Berkeley and Los Angeles: University of California Press, 1997).

35 See Hans Dahlke. "Nachbemerkung: Waffen für Amerika," in Lion Feuchtwanger: Dramen II, ed. by Hans Dahlke (Berlin: Aufbau, 1984), 774.

36 Today the best biographies on Benjamin Franklin are: H. W. Brands. The First American: The Life and Times of Benjamin Franklin (New York: Anchor Books, 2000); and Walter Isaacson. Benjamin Franklin. An American Life (New York: Simon and Schuster, 2003). For a recent biography 
the Franco-American military alliance of 1778 - an alliance that helped the Americans gain and protect their freedom against their British oppressors in the War of Independence (1775-1783). Franklin, who had thus successfully established a viable democracy, was a former scientist. In the late 1740s, he had ingeniously invented the lightning rod and other remarkable designs like the Franklin stove or the Glass Harmonica. In all respects, he seemed a wise, witty and, at times, even cunning man who was the very embodiment of progress. Because Franklin had forged the Franco-American military alliance during his prolonged stay (between 1776 and 1785) as American ambassador at Versailles and in Paris, Feuchtwanger called his play Waffen für Amerika (Arms for America).

In an explanatory note from 1954, Feuchtwanger later pointed out that his own personal experience of exile in France and America had made it quite clear to him that a deep historical bond existed between Europe and North America. Living in America also allowed Feuchtwanger to come to grips with the quintessential American character of Franklin - a man whom he had only been able to study, analyze, and understand from a European perspective before he had moved to and settled in the United States. ${ }^{37} \mathrm{~A}$ theater play on the famous eighteenth-century character Franklin allowed him to analyze both historical and contemporary events on the two continents.

By carrying out his analytical comparison, Feuchtwanger implies certain parallels: He sees certain historical processes at work and he sees a wide range of characters and political opinions contributing to American success. It must be noted that by this time, in the mid-1940s - other than in the 1920s - Feuchtwanger had become genuinely interested in the continuing process of history. He was interested in an understanding of history that was still part of the present. Accordingly, he did not simply want to mirror contemporary events in episodes of the past. By composing his play Waffen für Amerika, Feuchtwanger wanted to teach a historical lesson, a lesson about the course of history.

Feuchtwanger conceded that the dramatic key events of 1933, 1939, and 1941 - the National Socialists' rise to power, the outbreak of World War II and the forging of a military alliance of Britain, the USA, and the Soviet Union against Hitler - had not only changed his view of the world, but also his understanding of the role and function of the theater. "The message of my latest plays," he confessed, "differs from the philosophy of my earlier pieces." ${ }^{38}$ Benjamin Franklin,

in German see Jürgen Overhoff. Benjamin Franklin. Erfinder, Freigeist, Staatenlenker (Stuttgart: Klett-Cotta, 2006). Feuchtwanger was informed about Franklin's life by the best Franklin biography of his time: Carl van Doren. Benjamin Franklin (New York: Viking Press, 1938).

37 See Lion Feuchtwanger. "Zu meinem Roman 'Waffen für Amerika (1954)'," in Lion Feuchtwanger, Ein Buch nur für meine Freunde (Frankfurt am Main: Fischer, 1984), 394-402.

38 "Nun haben natürlich die wüsten und großartigen Geschehnisse der [vergangenen Jahre] mein Weltbild verändert, und die Botschaft der späteren Stücke entstammt einer anderen Philosophie 
Feuchtwanger held, had been engaged in a fight for a particular kind of political progress. It was the same historical progress that America under President Franklin D. Roosevelt tried to secure in the epic military battle against Hitler.

Feuchtwanger compared history with a flowing river ("the process of history is a kind of flow"), ${ }^{39}$ and America had been wise enough to always set her sails in the right direction, moving smartly and swiftly on the river of progress. The Nazis, on the other hand, had been foolishly trying to stem their country against progress, freedom, democracy, social justice, and religious toleration. Thus, they were to be swept away, rather sooner than later, by the Americans in a crushing defeat. Feuchtwanger never doubted that America and her allies would gain victory in the form of a full and comprehensive defeat of the Nazis.

The values of true progress, freedom, democracy, social justice, and religious tolerance would prove to be stronger than the racist doctrines of the fascists. The values of true progress were core American values - and if one wanted to understand these American values, one had to understand the most worthy and dignified of all Americans, Benjamin Franklin. If one understood Benjamin Franklin, grasping the wise and smart way he thought and acted, one would understand progress. One could then finally act in full accordance with it. Feuchtwanger therefore wanted to have Franklin acting on the stage in a way so the audience - following the American statesman's thoughts and actions closely - could and indeed would learn an important historical lesson, a lesson about the mechanism of historical progress itself.

Feuchtwanger was certain that the dynamics of historical progress never came to a halt - whether in 1776, in 1783 or in 1943. If progress was to be depicted as the real hero ${ }^{40}$ of his theatrical production, then the historical lesson of his play would be that progress could only be achieved by strong and powerful political coalitions - sometimes coalitions of antagonist forces like the Americans and the Soviets, with the help of the French and the British. In Waffen für Amerika, Feuchtwanger developed a concept of human progress achieved through a European-American co-operation that was only to be understood with regard to similar coalitions in earlier phases of transatlantic history. The concept of a European-American cooperation was one that he felt would survive, despite all the chauvinists on both sides of the Atlantic.

How did Feuchtwanger set out in late 1943 and early 1944 to teach his historical lesson on stage with the greatest possible effect? Feuchtwanger portrayed Franklin

als die der früheren," Feuchtwanger, Vorwort zu den "Drei Stücken”, 669.

39 "Geschichte [ist] etwas Fließendes," Feuchtwanger, Vorwort zu den "Drei Stücken”, 669.

40 Lion Feuchtwanger. "Nachwort des Autors von 1952," in Lion Feuchtwanger, Die Füchse im Weinberg (Berlin: Aufbau, 2008), 981: "Der Held [ist] nicht Benjamin Franklin [...], sondern jener unsichtbare Lenker der Geschichte [...]: der Fortschritt" [The hero [is] not Benjamin Franklin [...], but that invisible driving force of history [...]: progress]." 
as a person who acted reasonably - always -, who acted honestly, and who combined a polite conduct with cunning persistency and stamina. Franklin always knew precisely what his political goals were and he never lost sight of them. He never lost faith in progress. This becomes particularly obvious in Act 1, Scene 3, when Franklin meets with Queen Marie-Antoinette and the ladies and gentlemen of the French High Aristocracy. They ask him how he felt when he sailed from America to France, always knowing that, once captured by the British Fleet, he would have faced the gallows as a traitor: "How could you possibly endure on board the ship? Did you not die for fear? Did you not see the gallows before your eyes all the time?" 41 But Ben Franklin coolly replies: "On board the ship I was occupied with my studies, I studied the Gulf stream, the swift and warm Atlantic ocean current." 42

Then a High Officer at the French Court remembers how calm Franklin actually was when he received depressing information about the imminent defeat of the Continental Army in early 1777. The American ambassador to France simply continued to lecture at the French Academy about electricity, lightning and great storms:

In early summer, we received news about the thirteen American Colonies, learning that they were as good as defeated. At that time, Doctor Franklin lectured at the Academy about meteorology. The tranquility with which he talked was just admirable. And his humour - under these circumstances. ${ }^{43}$

Franklin then explains his creed: "I believe in my cause. Even in the darkest hour, I said to myself: It will work out in the end." ${ }^{4} 4$ The French Queen Marie-Antoinette is deeply moved and impressed by Franklin's firm belief in the inevitable power of progress: "This sounds like a prayer in church." ${ }^{45}$ Franklin smiles at her, and he continues to openly propagate what he thinks is indeed "pleasing to God." 46 Then he recites the Preamble of the American Declaration of Independence: "We hold these truths to be self-evident, that all men are created equal, that they are

41 "Wie haben Sie das nur ausgehalten auf dem Schiff? Sind Sie nicht gestorben vor Angst? Haben Sie nicht immerzu den Galgen vor Augen gehabt?”, Feuchtwanger, Waffen für Amerika, 425.

42 "Ich habe mich mit Studien befaßt, zum Beispiel über den Golfstrom," Feuchtwanger, Waffen für Amerika, 425.

43 "Im Frühsommer traf hier die Nachricht ein, daß die dreizehn amerikanischen Kolonien so gut wie besiegt seien. Um diese Zeit hielt Doktor Franklin in der Akademie seine große Rede über die Wetterkunde. Es war bewundernswert, mit welcher Ruhe Sie sprachen, und mit wieviel Humor [...] Unter solchen Umständen," Feuchtwanger, Waffen für Amerika, 427

44 "Ich glaube an meine Sache. Wenn es noch so schwarz aussah, ich sagte mir: und es geht doch," Feuchtwanger, Waffen für Amerika, 428.

45 "Das klingt ja wie in der Kirche," Feuchtwanger, Waffen für Amerika, 428.

46 "Gott wohlgefälli[g]," Feuchtwanger, Waffen für Amerika, 429. 
endowed by their Creator with certain unalienable Rights, that among these are Life, Liberty and the pursuit of Happiness." ${ }^{77}$

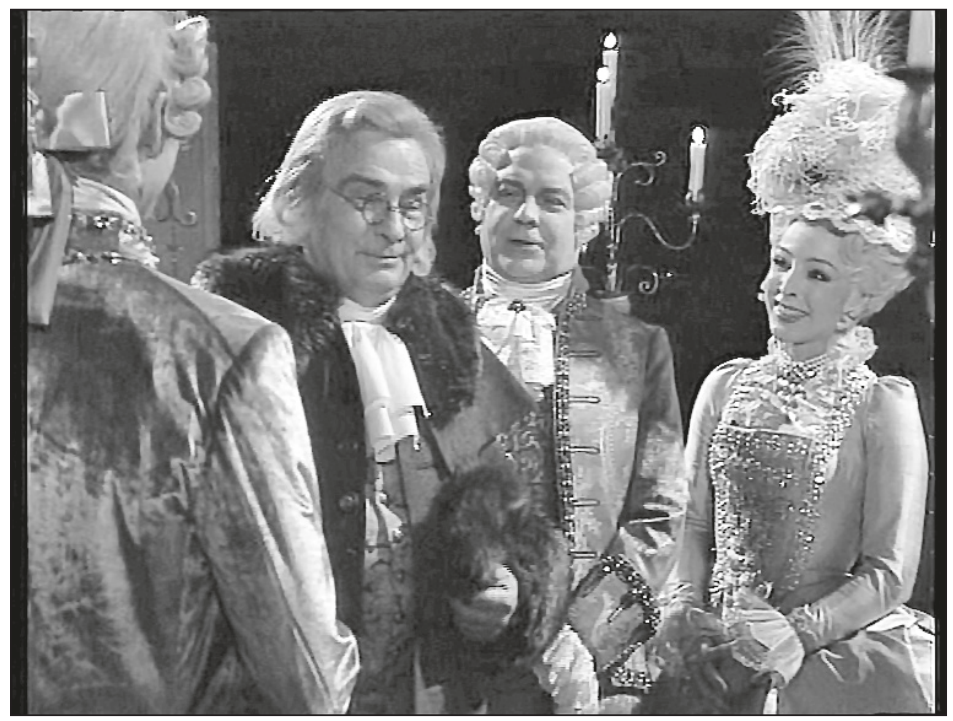

Fig. 1: Still from the German ZDF TV-Adaptation Waffen für Amerika, starring Arno Assmann as Benjamin Franklin, directed by Heinz Schirk (1976).

Feuchtwanger thus wants to let the audience feel Franklin's firm belief in republicanism, liberalism, and democracy. He wants to let them feel the truthfulness of his principles and the inevitability of progress. He wants to make them see the stupidity and futility of acting against what seems to be the preordained course of history. He pushes his audience to shy away from acting against freedom, against the democratic constitution, or against equality. Any actor who performs the role of Franklin on stage has to convey a sense of the utmost certainty that the "good guys" will win even the fiercest battle in the darkest hour of mankind. For the audience of his day and age, Feuchtwanger had this simple but earnest message: Roosevelt will defeat Hitler, there is not a shadow of doubt about this.

Fortunately, history was to prove Feuchtwanger right. The United States of America - founded by Benjamin Franklin in 1776 and wisely led by President Franklin D. Roosevelt from 1933 to 1945 - won the decisive battles against Nazi Germany

47 "Wir halten dafür, daß die nachfolgenden Wahrheiten keines weiteren Beweises bedürfen: Alle Menschen sind gleich geschaffen. Sie sind von ihrem Schöpfer ausgestattet mit gewissen unveräußerlichen Rechten, als da sind Leben, Freiheit und Streben nach Glück," Feuchtwanger, Waffen für Amerika, 429. 
in Western Europe. Soon after this epic victory, defeated Germany was divided into four occupied zones and then in two parts, East and West: The Federal Republic of Germany was established in 1949 with the support of the Americans, while the German Democratic Republic (GDR) was founded in the same year under the protection of the Soviet Union. In Germany, Feuchtwanger's Waffen für Amerika was first performed seventeen years after the end of the Second World War - in the GDR: Under the direction of Wolfgang Wischnewski, the play was put on stage in Zwickau in Saxony. From October 1962 to the summer of 1963, it was performed in the Stadttheater Zwickau over 20 times and it was apparently well. received by the audience. ${ }^{48}$

In West Germany, Waffen für Amerika was first seen on TV in the following decade. The public-service channel ZDF broadcasted an adaptation directed by Heinz Schirk on 29 June 1976, just one week before 4 July 1976 - precisely 200 years after the founding of the United States by Franklin and the other signers of the Declaration of Independence. The ZDF version of Feuchtwanger's play, with a strong cast ${ }^{49}$, was aired again on German TV in 2010. The director Schirk was particularly keen on lending Feuchtwanger's eighteenth-century story the authentic flair of pre-revolutionary France. He decided to insert a number of musical interludes in Feuchtwanger's play, with one of the actors singing diatribes against Queen Marie-Antoinette and her haughty manners. ${ }^{50}$ Still today, Schirk's congenial version of Feuchtwanger's Waffen für Amerika has a strong effect on the viewer.

When he completed his play Waffen für Amerika in April 1944, ${ }^{51}$ Feuchtwanger clearly and explicitly had the intention to teach a historical lesson - and he wanted to thank America. Unfortunately, America was not grateful to Feuchtwanger in the same way. During the McCarthy era, Feuchtwanger became the target of suspicion as a socialist or even communist intellectual. This was the time when US Senator Joseph McCarthy (Republican, Wisconsin) effectively spread fear of Communist influence. It was a period characterized by severe political repression. McCarthyism began in 1947 and lasted until 1956. As early as 1947, Feuchtwanger wrote a play about the Salem Witch Trials, Wahn oder der Teufel in Boston (Delusion, or The Devil in Boston), again a historical drama, set in seventeenth century Massachusetts. Thus, Feuchtwanger anticipated the theme of Arthur Miller's 1953 play The Crucible.

48 Dahlke, "Nachbemerkung: Waffen für Amerika," 782

49 Queen Marie-Antoinette: Christine Böhm; Minister Maurepas: Walter Rilla; Benjamin Franklin: Arno Assmann.

50 This was mentioned by Heinz Schirk in a telephone interview with the author of this article on 4 March 2019.

51 Dahlke, "Nachbemerkung: Waffen für Amerika," 774. 
At the end of his life, he dealt with Jewish themes again and advocated a Jewish state in Palestine, a state that came into being in 1948. Feuchtwanger never returned to Germany, either East or West, despite the fact that in 1953 he won the National Prize of the GDR First Class for Art and Literature - as a communist sympathizer, the GDR held him in high esteem until his death in late 1958. His wife Marta stayed in America, too. She continued to live in California in Villa Aurora and remained an important figure in the exile community, devoting the remainder of her life - she died in 1987 - to the work of her husband. She donated her husband's library, photographs, and personal papers and manuscripts to the Feuchtwanger Memorial Library, housed within the Doheny Memorial Library at the University of Southern California, Los Angeles (USC).

The Feuchtwanger special collection at USC is a living memory of German emigration to the United States in the 1930s - and it is a constant source for research on German-American educational history, a sub-discipline of transatlantic history, of which Feuchtwanger's play Waffen für Amerika will always remain an intriguing and important part. As Feuchtwanger predicted in one of his last public statements in November 1958: "Obviously, both the fate and the effect of my plays have not yet been fully accomplished." ${ }^{2}$. He was hoping that most of his plays, including Waffen für Amerika, would be understood much better "not in ten years' time, but in fifty years." 53 Less than four weeks before his death, Feuchtwanger dreamed of a much more empathic and understanding reception of his plays in the twenty first century: "I am looking forward to it." 54

\section{Cited Works}

Alt, Peter-André. Schiller. Eine Biographie, vol. 1 (1759-1791). München: C. H. Beck, 2000.

Bahr, Erhard. Weimar on the Pacific. German Exile Culture in Los Angeles and The Crisis of Modernism. Berkeley and Los Angeles: University of California Press, 2007.

Brands, Henry William. The First American: The Life and Times of Benjamin Franklin. New York: Anchor Books, 2000.

Brecht, Bertolt. "Vergnügungstheater oder Lehrtheater," in Werke. Große kommentierte Berliner und Frankfurter Ausgabe, ed. by Werner Hecht, Jan Knopf, Werner Mittenzwei and Klaus-Detlef Müller, Vol. 22: Schriften 2, Teil 1 (Berlin, Weimar, Frankfurt: Aufbau, Suhrkamp, 1992), 106-116.

Dahlke, Hans. "Nachbemerkung: Waffen für Amerika," in Lion Feuchtwanger: Dramen II, ed. by Hans Dahlke (Berlin: Aufbau, 1984), 774-782.

Dahlke, Hans. "Nachwort. Lion Feuchtwanger als Dramatiker," in Lion Feuchtwanger: Dramen II, ed. by Hans Dahlke (Berlin: Aufbau, 1984), 685-718.

Doren, Carl van. Benjamin Franklin. New York: Viking Press, 1938.

52 "Abgeschlossen ist das Schicksal und die Wirkung der Stücke offenbar noch nicht," Lion Feuchtwanger. "Vorwort zu 'Stücke in Prosa', in Lion Feuchtwanger: Dramen II, ed. by Hans Dahlke (Berlin: Aufbau, 1984), 671.

53 "nicht in zehn Jahren, [...] sondern in fünfzig," Feuchtwanger, Vorwort zu "Stücke in Prosa”, 671.

54 "Ich warte darauf," Feuchtwanger, Vorwort zu "Stücke in Prosa", 671. 
Feuchtwanger, Edgar and Bertil Scali. Hitler, My Neighbor. Memories of a Jewish Childhood, 19291939. New York: Other Press, 2017.

Feuchtwanger, Lion. Ein möglichst intensives Leben. Die Tagebücher, ed. by Nele Holdack, Marje Schuetze-Coburn and Michaela Ullmann. Berlin: Aufbau, 2018.

Feuchtwanger, Lion. "Nachwort des Autors von 1952," in Lion Feuchtwanger, Die Füchse im Weinberg (Berlin: Aufbau, 2008), 979-981.

Feuchtwanger, Lion. "Meine Schulzeit, ” in: Federleichte Mädchen. Das nymphenburger Lesebuch, ed. by. Dietz-Rüdiger Moser (München: Nymphenburger, 1991), 200-202.

Feuchtwanger, Lion. Heinrich Heines "Der Rabbi von Bacherach". Eine kritische Studie. Frankfurt am Main: Fischer, 1985.

Feuchtwanger, Lion. "Neunzehnhundertachtzehn. Ein dramatischer Roman," in Lion Feuchtwanger: Dramen I, ed. by Hans Dahlke (Berlin: Aufbau, 1984).

Feuchtwanger, Lion. "Vorwort zu den 'Drei Stücken'”[1934], in Lion Feuchtwanger: Dramen II, ed. by Hans Dahlke (Berlin: Aufbau, 1984), 665-668.

Feuchtwanger, Lion. "Vorwort zu 'Stücke in Prosa”" [1936], in Lion Feuchtwanger: Dramen II, ed. by Hans Dahlke (Berlin: Aufbau, 1984), 668-671.

Feuchtwanger, Lion. "Heinrich Heine und Oscar Wilde. Eine psychologische Studie," in Lion Feuchtwanger, Ein Buch nur für meine Freunde (Frankfurt am Main: Fischer, 1984), 17-30.

Feuchtwanger, Lion. "Zu meinem Roman 'Waffen für Amerika (1954)',' in Lion Feuchtwanger, Ein Buch nur für meine Freunde (Frankfurt am Main: Fischer, 1984), 394-402.

Feuchtwanger, Lion. "Aischylos, Syrakus und Reinhardt," in Lion Feuchtwanger, Ein Buch nur für meine Freunde (Frankfurt am Main: Fischer, 1984), 172-175.

Feuchtwanger, Lion. Erfolg. Drei Jahre Geschichte einer Provinz. Berlin: Gustav Kiepenheuer, 1930.

Heilbut, Anthony. Exiled in Paradise. German Refugee Artists and Intellectuals in America from the 1930s to the Present. Berkeley and Los Angeles: University of California Press, 1997.

Heusler, Andreas. Lion Feuchtwanger. Münchner - Emigrant - Weltbürger. Salzburg: Residenz, 2014.

Innes, Christopher. Erwin Piscator's Political Theater: The Development of Modern German Drama. Cambridge: Cambridge University Press, 1977.

Isaacson, Walter. Benjamin Franklin. An American Life. New York: Simon and Schuster, 2003.

Jaretzky, Reinhold. Lion Feuchtwanger. Reinbek bei Hamburg: Rowohlt, 1984.

Overhoff, Jürgen. Benjamin Franklin. Erfinder, Freigeist, Staatenlenker. Stuttgart: Klett-Cotta, 2006.

Schulz, Eckhard. "Lion Feuchtwanger als Dramatiker.” Volksbühnen-Spiegel 18.7/8 (1972): 30-34.

Selbmann, Rolf. "'Hat in der Geschichte nicht immer entsprochen'. Lion Feuchtwanger als Schüler des Wilhelmsgymnasiums. Zu seinem 100. Geburtstag," in Wilhelmsgymnasium in München. Jahresbericht 1983/84, ed. by Wilhelmsgymnasium (München, 1984), 94-106.

Specht, Heike. Die Feuchtwangers. Familie, Tradition und jüdisches Selbstverständnis im deutsch-jüdischen Bürgertum des 19. und 20. Jahrhunderts. Göttingen: Wallstein, 2006.

Sternburg, Wilhelm von. Lion Feuchtwanger. Die Biografie. Berlin: Aufbau, 2014.

Villa Aurora, URL: https://www.vatmh.org/en/artists-residence.html (accessed September 6, 2019).

Waffen für Amerika. Heinz Schirk, dir. (West Germany, 1976)

Weiß, Dietrich. Aus der Geschichte der jüdischen Gemeinde von Feuchtwangen 1274-1938. Feuchtwangen, 1991. 